THE USE OF MARKET INFORMATION IN PRICING

DEPOSIT INSURANCE

by James B. Thomson

James B. Thomson is an economist at the Federal Reserve Bank of Cleveland. The author thanks Ed Kane, Andy Chen, Eric Rosengren, and the referees of the Journal of Money, Credit and Banking for helpful comments on an earlier version of this paper.

Working papers of the Federal Reserve Bank of Cleveland are preliminary materials, circulated to stimulate discussion and critical comment. The views stated herein are the author's and not necessarily those of the Federal Reserve Bank of Cleveland or of the Board of Governors of the Federal Reserve System.

August 1986

Federal Reserve Bank of Cleveland 


\section{The Use of Market Information in Pricing Deposit Insurance}

\section{Abstract}

This paper argues that information about the value of the deposit-insurance guarantee is available from market-generated data. Under certain assumptions, an unbiased estimate of the market value of the deposit guarantee is readily available. In practice, however, it is only possible to observe a lower bound against which estimates of deposit-insurance premia can be compared.

In the absence of deposit-insurance reforms, the total guarantee associated with federal deposit insurance includes: 1) the guarantee on insured deposits, 2) a conditional guarantee on uninsured deposits, and 3) a conditional guarantee of the stockholders' residual claim on the future earnings of the bank.

\section{$\underline{\text { Introduction }}$}

The debate on pricing deposit insurance has gone from a purely academic concern to a public policy concern. The Federal Deposit Insurance Corporation (1983), the Federal Home Loan Bank Board (1983), and the U.S. Treasury Department (The Working Group of the Cabinet Council on Economic Affairs 1985) have all issued reports on risk-based deposit-insurance pricing. These execu- 
tive-agency studies accompany a large body of academic research on deposit-insurance pricing (see, for example, Avery, Kawst, and Hanweck [1985]; Horvitz [1983]; Kane [1983, 1985, and 19861; Merton [1977, 19781; Pyle 11983, 19861; Rochester and Walker [1985]; and Ronn and Verma [1985]).

If the Federal Deposit Insurance Corporation (FDIC) charges a deposit-insurance premium equal to the risk premium the market would require to provide the same level of risk-bearing services, then the insurance is appropriately priced.' The purpose of this paper is to show (1) that if unconditionally uninsured depositors exist, the market's ex ante estimate of the fair value of deposit insurance can be observed; and (2) in the absence of deposit-insurance reforms, the deposit insurance guarantee consists of the deposit insurance put on the insured deposits, a conditional guarantee on the uninsured deposits, and a conditional guarantee of the stockholders' residual claim on the future earnings of the bank.

Section I of this paper, which outlines the assumptions used in the analysis, shows that if banks are closed when they are found to be insolvent, and uninsured depositors and stockholders bear their full share of the losses, then the fair value of the deposit guarantee on $\$ 1$ of insured deposits is the risk premium paid on $\$ 1$ of uninsured deposits. Section II relaxes the assumption that the FDIC always closes banks that are found to be insolvent at the time of examination. ${ }^{2}$ With FDIC forbearances, the observed risk premium on $\$ 1$ of uninsured deposits is a lower bound estimate of the fair value of the 
deposit guarantee on $\$ 1$ of insured deposits. Section III presents a numerical example showing how market information could be used in calculating the fair value of the deposit guarantee. The paper's conclusions are presented in section IV.

\section{The Market Value of Deposit Guarantees without FDIC Forbearances}

The following assumptions are used in this analysis:

1) Market efficiency. This assumption is necessary if the market participants are to provide an accurate estimate of the risk of the bank. The semi-strong form of the efficient-markets hypothesis and dissemination of adverse information regarding insured banks is required for the analysis to hold.

2) The absence of external social benefits associated with the provision of federal deposit insurance at the margin. If the social benefits associated with the last dollar of deposit-insurance coverage exceed the private benefits associated with the last dollar of deposit-insurance coverage, then the market premium is not the socially optimal deposit-insurance premium (see Merrick and Saunders [1985]).

3) All bank liabilities are homogeneous deposit liabilities. The bank is assumed to issue one type of deposit that matures on the same day the bank is examined and the deposit guarantee is repriced. This is assumed for expositional simplicity. All that is required for the analysis to hold is that the bank issue some uninsured. deposit liabilities that mature on the examination date (possibly large negotiable CDs). 
4) Frictionless markets. The absence of transaction costs and indivisibilities in the deposit and insurance markets ensures that arbitrage can remove pricing errors when they occur. The size of the transaction costs and the indivisibilities limits the degree of pricing error that cannot be removed by arbitrage.

5) No FDIC forbearances. The F.DIC closes all banks that are insolvent. Stockholders of banks with a positive net worth that falls below the statutory (or regulatory) minimum capital requirements are given the option of increasing the capital in the bank or allowing the deposit guarantor to close the bank. Banks with positive net worth that exceeds the statutory (or regulatory) minimum capital requirements are allowed to pay out the excess net worth to their stockholders. This is a counterfactual assumption. It assumes that the FDIC is capable of and willing to close banks when they are found to be insolvent. Negative net worth is a necessary, but not a sufficient, condition for the forced closing of a bank by the FDIC.'

The following notation is used throughout the paper:

$A \quad=$ value of the bank's assets,

$B_{t}=$ value of a $\$ 1$ risk-free discount bond at time $t$,

$D_{r}=$ value of the bank's deposits at time $t$,

$C(\bullet)=$ American call option,

$c(\bullet)=$ European call option,

$D \quad=$ the face value of $D$, at $t=T$,

$p(\bullet)=$ European put option. 
When 100 percent of a bank's deposits are insured, the value of the deposit-insurance guarantee equals the total value of risk-bearing services provided in the market by uninsured depositors when the bank issues only uninsured deposits. Merton (1977) shows that with 100 percent insurance the value of the deposit guarantee equals the European put option $p(A, T-t ; D)$, which allows the stockholders to sell the assets of the bank, $A$, to the depositors for the face value of their deposits, $D$, at time $t=T$. Following Merton (19741, in the absence of the deposit guarantee, the total value of risk-bearing services provided by the uninsured depositors is,

$$
D B_{t}-D_{t}=p(A, T-t ; D)
$$

By Merton's (1973) Theorem 6, and by letting $D_{0} / D=d_{0}$ and AID $=a$, the value of the deposit guarantee (risk-bearing services) on $\$ 1$ of insured (uninsured) deposits at $t=0$ is:

$$
B_{0}-d_{0}=p(a, T ; 1)
$$

The result in equation (2) has little practical use in pricing deposit guarantees if it only holds when all of the bank's deposits are either insured or uninsured. If 100 percent of the banks deposits are insured, then $B_{0}-d_{0}$ cannot be observed. If the uninsured depositors and the deposit guarantor have the same priority of claim against the assets of the bank, relaxing the assumption of full or no insurance to allow for partial insurance of the bank's deposits does not affect equation (2). ${ }^{4}$ To see this, let w, 
be the percentage of the bank's deposits that are uninsured $\left(w_{i}+w_{u}=1\right)$. The stockholders now hold two put options: $p\left(w_{i} A, T-t ; w_{i} D\right)$ issued by the FDIC and $p\left(w_{U} A, T-t ; w_{1} D\right)$ issued by the uninsured depositors. By Merton's (1973) Theorem 6, the total value of the stockholders' put options at $t=0$ is:

$$
p\left(W_{u} A, T ; W_{u} D\right)+p\left(W_{i} A, T ; W_{i} D\right)=\left(W_{i}+W_{u}\right) p(A, T ; D) .
$$

By definition, $w_{1}+w_{1 s}=1$. Therefore, a bank does not affect the value of risk-bearing services provided by the uninsured depositors (FDIC) on each dollar of uninsured (insured) deposits by issuing $W, D$ insured $\quad(W, D$ uninsured) deposits. The total value of the deposit guarantee is $w_{i} D\left(B_{0}-d_{0}\right)$.

\section{The Analysis with Federal Bailouts of Insolvent Banks}

This section relaxes assumption 5 of section I by assuming that a set of constraints, $z$, exists that affects the FDIC's ability to close insolventbanks. ${ }^{5}$ The analysis shows that with FDIC forbearances, the risk premium paid on the explicitly uninsured deposits is the lower bound of the market's valuation of the deposit guarantee. Furthermore, the cost of the guarantee is shown to increase when the stockholders' position in the bank is not closed out when the bank is found to be insolvent.

Let $q(z)$ be the probability that at the next examination date the bank is insolvent and the FDIC is unable to close it. Following Kane (1986), $z$ is assumed to be a single index function, which consist of information 
constraints, staff constraints, the reserve position of the insurance fund, and political and legal constraints on the FDIC's ability to close insolvent banks. If the insolvent bank is allowed to operate, the FDIC may choose to operate it as a mutual institution (that is, close out the position of the existing shareholders) or allow the equity holders to retain their position. Initially, it is assumed that the equity holders are closed out.

If a bank is found to be insolvent, both the FDIC and the uninsured depositors have the right to force the closing of the bank. If the FDIC wishes to allow the bank to operate until the next examination day, it must buy out the position of the uninsured depositors or guarantee value of the uninsured depositors' claim against the bank. The FDIC must provide a guarantee of at least the market value of the uninsured depositors' claim on the bank at the time of examination to keep the uninsured depositors from forcing a liquidation of the bank. ${ }^{6}$ It is assumed that the same set of constraints, $z$, that prevents the FDIC from closing the bank, forces it to guarantee the face val ue of the uninsured deposits.'

The value of the guarantee on \$1 of conditionally uninsured deposits at $t=0$ is $q(z) p(a, T ; 1)$. The risk-bearing services provided by the conditionally uninsured depositors on $\$ 1$ of deposits at $t=0$ is:

(4)

$$
B_{0}-d_{0}-q(z) p(a, T ; 1)=(1-q(z)) p(a, T ; 1)
$$

The observed risk premium on $\$ 1$ of conditionally uninsured deposits is shown below in equation (5):

$$
R_{1}=(1-q(z))\left(B_{0}-d_{0}\right) .
$$


The fair value of the deposit guarantee on $\$ 1$ of insured deposits is now the observed risk premium on the conditionally uninsured deposits scaled by 1 , minus the probability that the FDIC will protect the conditionally uninsured depositor if the bank is found to be insolvent. ${ }^{8}$ The total value of the deposit-insurance subsidies and guarantees is:

$$
G=w_{i} D\left(B_{0}-d_{0}\right)+q(z) w_{u} D\left(B_{0}-d_{0}\right)
$$

Because $q(z)$ is not observed, the market's estimate of the fair value of the deposit guarantee cannot be observed. However, since $q(z)$ is less than or equal to 1, the risk premium paid on the conditionally uninsured deposits represents the minimum value of the deposit-insurance guarantee. It is a lower bound that can be used to evaluate empirical estimates of the fair value of the deposit guarantee. The upper bound of the fair value of the deposit guarantee would be reflected in the risk premium of the subordinated debt issued by the bank.

Equation (6) assumes that the stockholders' position is closed out when the bank is found to be insolvent. Let $y(z)$ be the probability that on the next examination day the bank is insolvent, and the stockholders retain their position in the bank. By failing to always close out the stockholders' position in insolvent banks, the FDIC has changed the value of the call option, $C_{e}$, which represents the equity of the bank and is now equal to $\operatorname{Max}\left[y(z) C_{e}, A-D\right]$. The value of the call option $G$ can be broken down into two components: the value of the equity without the deposit-insurance subsidy $C_{s}=\operatorname{Max}(0, A-D)$ and the deposit-insurance subsidy $x=\operatorname{Max}\left[y(z) C_{e}, 0\right]$. The total value of the deposit-insurance subsidies and guarantees at $t=0$ is now:

$$
G^{\prime}=G+x=w_{i} D\left(B_{0}-d_{0}\right)+q(z) w_{u} D\left(B_{0}-d_{0}\right)+x .
$$


Therefore, allowing the stockholders to retain their residual claim on the assets and future earnings of the bank increases the value of the deposit guarantee.

\section{Market Estimates of the Deposit Guarantee}

To demonstrate how market information can be used in pricing the deposit guarantee, the yields on six-month (secondary market) Treasury bills, bank certificates of deposit (CDS), and prime commercial paper (CP) are collected.' The yields are the daily quoted ones reported in the Federal Reserve Board's statistical release H.15, "Selected Interest Rates," for the trading day closest to January 1 and July 1 for each year 1980 through 1985. All reported yields are converted to bond-equivalent ones. An annual yield is computed for each instrument by taking the geometric average of its six-month yield in January and July for that year.

The risk premium on CDS $(C P)$ is calculated as the difference between the annual yield on CDs '(CP) and T-bills. ${ }^{\circ}$ Assuming 10 percent insurance and different values of $q(z)$, the value of the deposit guarantee is estimated from the risk premium on the CDs. ${ }^{1}$ By equation (5), the value of the guarantee on $\$ 1$ of insured deposits is $R_{u} /(l-q(z))$. The value of the guarantee on $\$ 1$ of conditionally uninsured deposits is $q(z) R_{u} /(1-q(z))$.

Table 1 presents numerical estimates of the value of the deposit guarantee on $\$ 1$ of insured and conditionally uninsured deposits for 1980 to 1985 . Two points are brought out in the table. First, the value of the guarantee on the 
conditionally uninsured deposits is a positive function of $q(z)$. Second, the value of the deposit guarantee on insured and conditionally uninsured deposits varies across years. If $q(z)$ is not known, then the observed risk premium on the conditionally uninsured deposits can only be used as the lower bound against which estimates of the deposit guarantee can be compared. As seen in table 1, the degree to which the observed lower bound can be used to fine-tune risk-based models of deposit guarantees decreases as $q(z)$ increases.

One way of making $q(z)$ observable is to force banks to issue discount bonds that can be insulated from the deposit guarantees. '2 ${ }^{2}$ These bonds would have the same maturity as the deposit insurance put and the same priority of claim on the bank as deposits. The risk premium on $\$ 1$ of this debt is $R_{\mathbf{b}}=B_{0}-d_{0}$. The value of the deposit guarantee on insured deposits $\left(B_{0}-d_{0}\right)$ is now observable. In addition, $q(z)$ and the value of the guarantee on conditionally uninsured deposits $\left(q(z)\left(B_{0}-d_{0}\right)\right)$ can now be computed as:

(8)

$$
q(z)=1-R_{u} / R_{b} \text {. }
$$

\section{Conclusion}

The market provides information on the value of deposit guarantees. Under restrictive assumptions, the value of the deposit guarantee is observable. In practice, however, only a lower bound can be observed. Under the current system of federal deposit insurance, the deposit guarantee consists of ( 1 ) the 
guarantee of the insured deposits, (2) a conditional guarantee of the bank's uninsured deposits, and (3) a guarantee of the stockholders' residual on the future earnings of the bank. Because the guarantee has real value to the banks' stockholders, insolvent banks should always be reorganized in a manner that closes out the position of the stockholders. 
$\underline{\text { Notes }}$

1. For purposes of exposition, this paper concentrates on the value of FDIC guarantees. The analysis is valid for all three federal deposit guarantors: the FDIC, the Federal Savings and Loan Insurance Corporation (FSLIC), and the National Credit Union Share Insurance Fund (NCUSIF).

2. Legally, the FDIC does not have the power to close insolvent banks. The FDIC must petition the bank's chartering agency to close the bank. However, this process is generally a formality, and, in practice, the FDIC is able to force the closing of insolvent banks.

3. See Kane (1986) for a discussion of the constraints faced by the FDIC that may prevent it from closing insolvent banks.

4. Currently, the deposit guarantee is explicitly extended to the first $\$ 100,000$ of each deposit account (this limit is per person, per account type, at each insured institution). If the deposit guarantee is not extended to the explicitly uninsured deposits, the statutory guarantee of only the first $\$ 100,000$ of any deposit does not affect the valuation of the portion of the deposit in excess of $\$ 100,000$. A proof of this is available from the author.

5. This is assumed for expositional simplicity. The analysis is still valid in cases where the purchase-and-assumption method is used to dispose of the bank (and any other technique used to handle a failing bank that leaves uninsured depositors whole).

6. It does not matter whether the FDIC buys out the uninsured depositors and issues insured deposits to replace them, or guarantees the market value of the uninsured deposits.

7. This assumption seems to hold in practice. Historically, the majority of failed banks have been disposed of using the purchase-and-assumption technique (see Barnett, Horvitz, and Silverberg [1977]).

8. If the bank is not required to pay for the conditional guarantee on its uninsured deposits, it receives a subsidy from the FDIC of $q(z)\left(B_{0}-d_{0}\right)$ on each dollar of conditionally uninsured deposits it issues. Competition among banks for conditionally uninsured deposits might result in a fraction, v,, of the subsidy being paid to the conditionally uninsured depositors. The observed risk premium on $\$ 1$ of conditionally uninsured deposits is $\mathbf{R}_{\mathbf{u}}=$ $\left(1-q(z)\left(1-v_{s}\right)\right)\left(B_{0}-d_{0}\right)$.

9. For expositional purposes, it is assumed that $x=0$.

10. The spread between the $T$-bill rate and the $C$ and $C P$ rates includes a tax differential because T-bills are not subject to state and local taxes, while CDs and $O P$ are. This makes the spreads wider than the true risk-induced spread and biases the deposit guarantee estimates upward. 
11. The CDs are assumed to be 10 percent insured because the current ceiling on insurance coverage is $\$ 100,000$, and the majority of widely traded CDs are of a $\$ 1,000,000$ denomination (see Stigum [1978]).

12. This, of course, assumes that $y(z)=0$. 


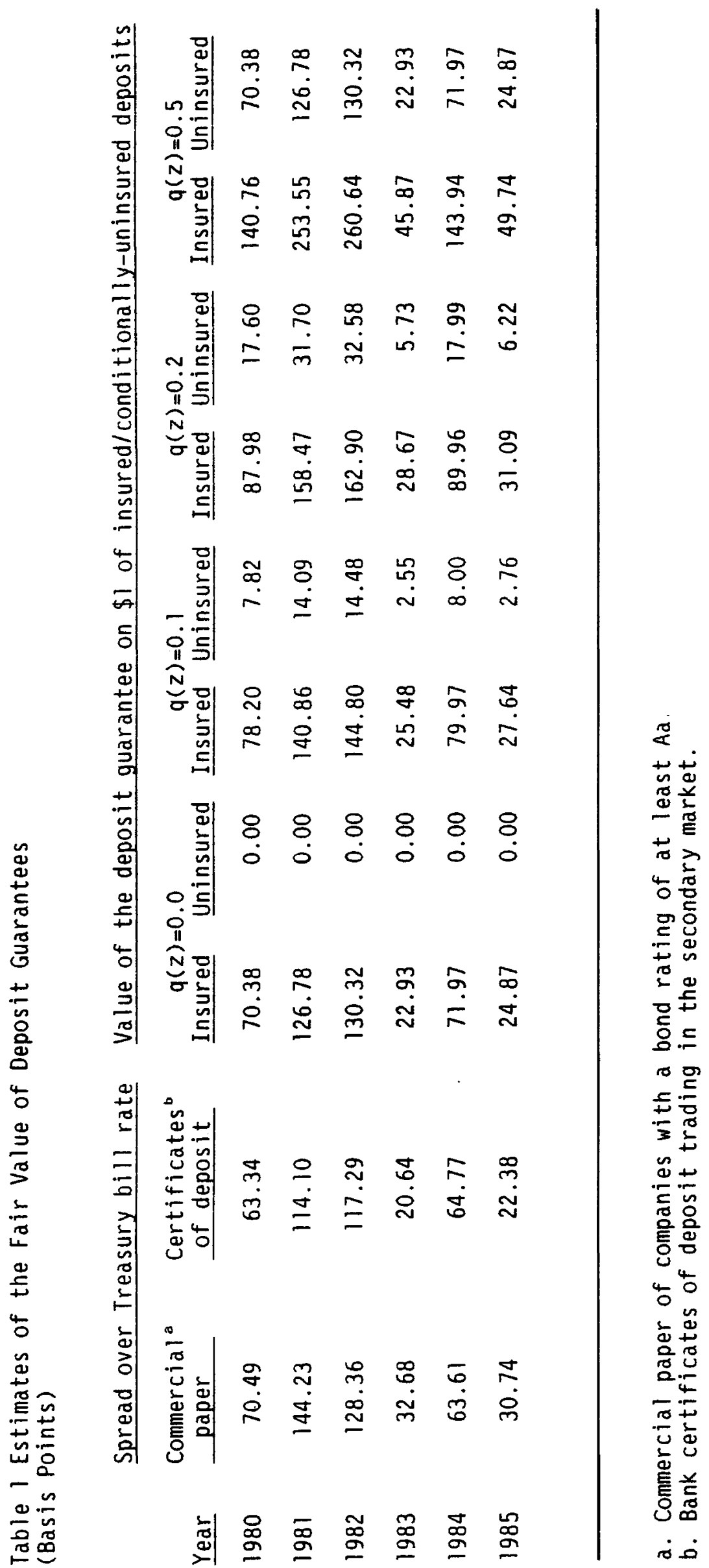




\section{$\underline{\text { References }}$}

Avery, Robert B., George A. Hanweck, and Myron L. Kwast. "An Analysis of Risk-Based Deposit Insurance for Commercial Banks." Proceedings of a Conference on Bank Structure and Competition, Chicago, IL: Federal Reserve Bank of Chicago, 1985, pp. 217-50.

Baer, Herbert. "Private Prices, Public Insurance: The Pricing of Federal Deposit Insurance," Economic Perspectives, Federal Reserve Bank of Chicago, vol. 9, no. 5 (September/October 1985), pp. 45-57.

Barnett, Robert E., Paul M. Horvitz, and Stanley C. Silverberg. "Deposit Insurance: The Present System and Some Alternatives," Banking Law Journal, vol. 94, no. 4 (April 1977), pp. 304-32.

Benston, George J. "Interest on Deposits and the Survival of Chartered Depository Institutions," Economic Review, The Federal Reserve Bank of Atlanta, October 1984, pp. 42-56.

Black, Fischer, and Myron Scholes. "The Pricing of Options and Corporate Liabilities," Journal of Political Economy, May/June 1973, pp. 637-54.

Brickley, James A., and Christopher M. James. "Access to Deposit Insurance, Insolvency Rules and the Stock Returns of Financial Institutions," Journal of Financial Economics, vol. 16 (July 1986), pp. 345-71.

Buser, Steven A., Andrew C. Chen, and Edward J. Kane. "Federal Deposit Insurance, Regulatory Policy, and Optimal Bank Capital," Journal of Finance, vol. 36, no. 1 (March 1981), pp. 51-60.

Campbell, Tim S., and David Glenn. "Deposit Insurance in a Deregulated Environment," Journal of Finance, vol. 39, no. 3 (July 1984), pp. 775-87.

Federal Deposit Insurance Corporation. Deposit Insurance in a Changing Environment. Washington, DC, April 1983.

Federal Home Loan Bank Board. Agenda for Reform: A Report on Deposit Insurance to the Conqress from the Federal Home Loan Bank Board. Washington, DC: Federal Home Loan Bank Board, March 1983.

Horvitz, Paul M. "The Case Against Risk-Related Deposit Insurance Premiums," Housing Finance Review, July 1983, pp. 252-63.

Kane, Edward J. "Appearance and Reality in Deposit Insurance: The Case for Reform," Journal of Banking and Finance, vol. 10, no. 2 (June 1986), pp. 175-88.

The Gathering Crisis in Federal Deposit Insurance. Cambridge, MA: MIT Press, 1985. 
- "A Six-Point Program for Deposit Insurance-Reform," Finance Review, July 1983, pp. 269-78.

Kaufman, George, and Gerald O. Beirwag. "A Proposal for Federal Deposit Insurance with Risk Sensitive Premiums," Occasional Papers of the Federal Reserve Bank of Chicago, March 16, 1983.

Marcus, Alan, J., and Israel Shaked. "The Valuation of FDIC Deposit Insurance Using Option-pricing Estimates," Journal of Money Credit and Banking, vol. 16, no. 4 (November 1984), pp. 446-60.

Mayer, Thomas. "A Graduated Deposit Insurance Plan," Review of Economics and Statistics vol. 47, no. 1 (February 19651, pp. 114-16..

McCulloch, J. Huston. "Interest-Risk Sensitive Deposit Insurance Premia: Stable ACH Estimates," Journal of Banking and Finance, vol. 9, no. 1 (March 1985), pp. 137-56.

- "Misintermediation and Macroeconomic Fluctuations," Journal of Monetary Economics, vol. 8, no.1 (July 1981), pp. 103-15.

Merrick, John J. Jr., and Anthony Saunders. "Bank Regulation and Monetary Policy," Journal of Money, Credit and Banking, vol. 17, no. 4 (November 1985), pp. 691-717.

Merton, Robert C. "On the Cost of Deposit Insurance When There are Surveillance Costs," Journal of Business, vol. 51, no. 2 (July 19781, pp. $439-52$.

- "An Analytic Derivation of the Cost of the Deposit Insurance and Loan Guarantees: An Application of Modern Option Pricing Theory," Journal of Banking and Finance, vol. 1, no. 1 (June 19771, pp. 3-11.

- "On the Pricing of Corporate Debt: The Risk Structure of Interest Rates," Journal of Finance, vol. 29 (May 1974), pp. 449-70.

"The Theory of Rational Option Pricing," The Bell Journal of Economics and Management Science, vol. 4, no. 1 (Spring 1973), pp. 141-83.

Peterson, Paul T. "The Case Against Risk-Related Deposit Insurance Premiums: A Contrary View," Housing Finance Review, July 1983, pp. 265-68.

Pyle, David H. "Capital Regulation and Deposit Insurance," Journal of Banking and Finance, vol. 10, no. 2 (June 1986), pp. 189-201.

- "Pricing Deposit Insurance: The Effects of Mismeasurement," Working Paper 8305, Federal Reserve Bank of San Francisco, October 1983. 
Rochester, David P., and David A. Walker. "A Risk-Based Deposit Insurance System." Manuscript 1985.

Ronn, Ehud I., and Avinash K. Verma. "Pricing Risk-Adjusted Deposit Insurance: An Option-Based Model," Working Paper, School of Business Administration, University of California at Berkeley, May 23, 1985.

Stigum, Marcia. The Money Market: Myth, Reality, and Practice. Homewood, IL: Dow Jones-Irwin, 1978.

Smith, Clifford W., Jr. "Option Pricing: A Review," Journal of Financial Economics, vol. 3 (January/March 1976), pp. 3-51.

The Working Group of the Cabinet Council on Economic Affairs. Recommendations for Change in the Federal Deposit Insurance System. Washington, DC: U.S. Treasury Department, January 1985. 